\title{
THE EFFECT OF SURFACTANT (SODIUM LAURYL SULPATE) AND DEMULSIFIER (HEXANE) ON CRUDE OIL EMULSION TREATMENT
}

\author{
Ifeanyi Samson Nwankwo, Bright Bariakpoa Kinate, Mohammed Othman \\ Department of Petroleum Engineering \\ Rivers State University, Port Harcourt, Rivers, Nigeria
}

Abstract - Crude oil emulsions pose significant problems to petroleum production and processing and as such have received serious attention towards providing lasting solutions to alleviate these production problems. The use of surfactants and demulsifiers has proven to be industry's most recognized method for the treatment of crude oil emulsions. In this study a laboratory investigation was carried out in order to determine the effect of surfactant, Sodium Lauryl Sulphate (SLS) and demulsifier (Hexane) on emulsion treatment at different concentrations. Two samples of crudes (IMOR3-023L and AGBDI-013L) were used with Sodium Lauryl Sulphate (SLS) as surfactant, Hexane as the demulsifier and Toluene as a stabilizer to form an emulsion. For each crude sample, eight (8) samples of emulsions were formulated with varying volume concentrations of the water, demulsifier and surfactant. For all the samples, Toluene (stabilizer) was kept constant while the demulsifier (Hexane) is kept constant and surfactant (SLS) varied for the first test. For the second test, the Hexane (demulsifer) was varied and SLS(Surfactant) was constant. The result shows that when Toluene and Hexane were kept constant with SLS varied, sample A has significant increase in the volume of water separated from $13 \mathrm{ml}$ to $16 \mathrm{ml}$ for range of $1 \mathrm{hr}$ to $5 \mathrm{hrs}$ and Sample B with volume of water separated from $3.8 \mathrm{ml}$ to $10.1 \mathrm{ml}$ for range of $1 \mathrm{hr}$ to $5 \mathrm{hrs}$. Similarly, sample C and D recorded significant increase also when Toluene and SLS was kept constant with Hexane varied. Sample I and sample $J$ has significant increase in the volume of water separated from $3 \mathrm{ml}$ to $9.9 \mathrm{ml}$ and $12 \mathrm{ml}$ to $12.9 \mathrm{ml}$ for range of $1 \mathrm{hr}$ to $5 \mathrm{hrs}$. In general, varying the volume of Hexane has higher percentage of water recovered and separated than SLS. This research has shown the effectiveness of chemical method for crude oil emulsion treatment and should be adopted as separation will be fast and less expensive.

Keywords-Demulsifiers, Hexane, Sodium Lauryl Sulphate , Stabilizers, Surfactant

\section{INTRODUCTION}

Water in Oil and Oil in water emulsion is a common problem encounter during and after crude oil production and requires cost effective separation techniques to meet market specification and discharge standard. Oil and water mixtures are usually not stable even when their droplets tends to merge together and requires an emulsifier to stabilize the emulsion (Pichot, 2012). The difficulty of separating wateroil emulsion mixture has been a subject of study for decades. Several chemical and physical methods have been proposed by many studies for separating emulsion mixtures with the use of surfactants standing atop as a result of its efficiency to separate oil molecules from water molecules at their boundary interface with economy (Siti-Nuurul-Huda, 2010).

Demulsifiers which are molecules that separate oil from water at low concentrations are important in breaking an emulsion system (Al-sabagh et al, 2011). The principle of demulsification by physical methods (separation/breaking of emulsions) is based on conductive heating aimed at breaking the oil-water interface via surface tension reduction and by centrifuging aimed at shaking off the less dense specie from the mixture. However, where there are remarkable concentrations of polar molecules with hydrophilic and hydrophobic ends, surface tension reduction by conductive heating are generally insufficient for breaking the crude oil emulsions. In this case, specially formulated complex organic compounds are generally applied or argument with physical methods (Raymond, 2003). These organic compounds are generally called surfactants.

During treatment, it is often necessary to keep the emulsion stable. This can be achieved by combining surfactants and colloidal particles. Surfactants are generally amphiphilic in nature and as a result will have a natural affinity for the oil-water interface which they eventually attack thereby reducing the oil-water interfacial tension and the energy required for the formation of emulsion. These adsorbed 


\section{International Journal of Engineering Applied Sciences and Technology, 2020 \\ Vol. 4, Issue 10, ISSN No. 2455-2143, Pages 9-15 \\ Published Online February 2020 in IJEAST (http://www.ijeast.com)}

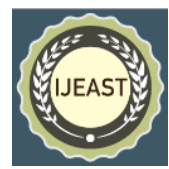

surfactant molecules at the interface act as electrostatic or steric barriers against droplet coalescence and increase the emulsion stability (Megahn, 2001). The extent of the hydrophilic-hydrophobic balance provided by the surfactant molecules will determine the resulting type of the emulsion being formed-water-in-oil or oil-in-water emulsion.

The colloidal particles used in emulsion stabilization are not amphiphilic. However, they are partly wettable in each of two immiscible phases which eventually favors the location of liquid-liquid interface (Golemanov, 2008). They do not like surfactants reduce the oil-water interfacial tension, but they are strongly adsorbed at the oil-water interface. This adsorption process is slow and more often than not, need to be enhanced.

Experimental investigation of the rheology and stability behavior of surfactant stabilized water-in-oilemulsion, showed that the behavior and stability of surfactant stabilized crude oil emulsion depend on viscosity, total acid and base number (Israel, 2016) and (Schubert \& Armbruster ,1992).

Previous investigation was performed in order to predict water-in-oil emulsion coalescence from surface pressure isotherms. A droplet of a solution of asphaltenes, $n$ heptane and toluene was formed and aged at the tip of a capillary in an aqueous medium. Irreversibly adsorbed films were observed to form rapidly at all asphaltene concentrations and rigid films form least rapidly at intermediate asphaltene concentration $\left(10 \mathrm{~kg} / \mathrm{m}^{3}\right)$. A "phase change" from a compressible film to an almost incompressible film occurred upon compression in most cases (Patricia, 2006).

The breaking of oil-water emulsion for improvement of oil recovery operations in the Niger delta oilfields has been investigated in which selected cationic surfactants were prepared and used to investigate their breaking potential on emulsions during enhanced recovery operations. It was observed that the surfactants were effective in separating oilwater emulsions expected during a surfactant/polymer (SP) process for improved oil recovery. (Ijogbemeye et al, 2012).

The evaluation of the actual effect of surfactants on crude emulsion systems is relevant if the effective use of surfactants needs to be achieved. The surfactants use of oil-water emotions produces result based on the type of surfactant, operating conditions and the properties of the emulsion system under consideration (Mazus, 2013). A number of analytical models based on modeling and simulation have been present for analyzing the effect of surfactants on crude oil emulsions. However, the major limitation of these analytical models is assumptions that did not properly describe the actual operation environment for surfactants application on emulsions. Although, these models are quicker and predictive in nature compared to laboratory analysis, the latter has been adopted as the most effective method for investigating surfactant effect on emulsion crude.

According to Orji and Duhu (2012), there are still many prevalent issues in the selection of demulsifiers for crude oil treatments. This is because, crude oil of different API gravity respond differently to several demulsifiers. In this study, laboratory investigation of the effect of surfactants and demulsifiers on crude oil emulsion treatment has been carried out to determine how different surfactants and demulsifier affect the volume of water recovered from the emulsion at varying operating conditions, giving rise to maximum recovery.

\section{MATERIALS \& METHOD}

Experimental procedures were carried out to investigate the effect of demulsifiers and surfactants on emulsion treatment. Two samples of crudes (IMOR-023L and AGBDI-013L) were used with Sodium Lauryl Sulphate (SLS) as surfactant and Hexane as the demulsifier. Toluene was used as a stabilizer in the process. For every crude sample, eight (8) samples of emulsions were formulated with varying volume concentrations of the water, demulsifier and surfactant. The treatment potential of the demulsifier and the surfactant was evaluated by the volume of water recovered. The detailed description of the laboratory procedures and the materials/apparatus are presented.

\section{A. Materials and Apparatus}

In this study, the materials/apparatus used include: Two (2) different crude oil samples, distilled water, Toulene (used as a stabilizer), Sodium Lauryl Sulphate, SLS (surfactant ), Hexane (demulsifier), sets of beakers, $100 \mathrm{ml}$ measuring cylinder, $25 \mathrm{ml}$ pycnometer, Red Wood Viscometer, weighing balance, $\mathrm{pH}$ meter, air coolers and wash bottles.

\section{B. Experimental Procedures}

Measuring cylinders and beakers were washed and dried. $100 \mathrm{ml}$ graduated measuring cylinder were labeled for different samples and were filled with the following volume ratio of water to crude oil: 15:20, 14:20, 13:20 and 12:20

respectively. Known sample of Toluene was added for the stability of the emulsion with different concentrations of surfactants (SLS) ranging from (1-4 ml) at constant volume of demulsifier (hexane). The sample mixture was agitated for about 2-5 minutes at room temperature and the volume of separation was observed on hourly basis for 5hours. The above procedures were repeated for each of the samples with the volume of SLS kept constant and hexane varied from $7 \mathrm{ml}$ to $10 \mathrm{ml}$. Emulsion formulation Sample preparation volume and composition is presented in Table 10 to Table 13 of Appendix A.

\section{RESULTS AND DISCUSSION}

The results of the experiment performed in this study are presented in this section and discussions are based on the findings/results obtained in order to explicitly explain the principle behind the observed behavior/trend and property 
changes. In Tables (1-4), the volume of water separated on hourly basics is presented for each case and test condition.

Table 1: Hourly Water Recovery of AGBDI - 013L Emulsion (Hexane and Toluene Volumes kept constant)

\begin{tabular}{|c|c|c|c|c|c|}
\hline Time & $\mathbf{1 ~ h r}$ & $\mathbf{2} \mathbf{~ h r s}$ & $\mathbf{3} \mathbf{~ h r s}$ & $\mathbf{4 h r s}$ & $\mathbf{5} \mathbf{~ h r s}$ \\
\hline SAMPLE A & $13 \mathrm{ml}$ & $14 \mathrm{ml}$ & $14.5 \mathrm{ml}$ & $15 \mathrm{ml}$ & $16.0 \mathrm{ml}$ \\
\hline SAMPLE B & $3.8 \mathrm{ml}$ & $6.5 \mathrm{ml}$ & $8.3 \mathrm{ml}$ & $9.9 \mathrm{ml}$ & $10.1 \mathrm{ml}$ \\
\hline SAMPLE C & $2.5 \mathrm{ml}$ & $4 \mathrm{ml}$ & $5.9 \mathrm{ml}$ & $7 \mathrm{ml}$ & $8.0 \mathrm{ml}$ \\
\hline SAMPLE D & $14 \mathrm{ml}$ & $14.7 \mathrm{ml}$ & $15.0 \mathrm{ml}$ & $15.2 \mathrm{ml}$ & $15.5 \mathrm{ml}$ \\
\hline
\end{tabular}

Table 2: Hourly Water Recovery of IMOR3-023L Emulsion (Toluene and Hexane constant)

\begin{tabular}{|l|l|l|l|l|l|}
\hline Time & $\mathbf{1} \mathbf{h r}$ & $\mathbf{2} \mathbf{h r s}$ & $\mathbf{3} \mathbf{h r s}$ & $\mathbf{4 h r s}$ & $\mathbf{5} \mathbf{h r s}$ \\
\hline SAMPLE E & $7.9 \mathrm{ml}$ & $8.5 \mathrm{ml}$ & $9.0 \mathrm{ml}$ & $10 \mathrm{ml}$ & $10.8 \mathrm{ml}$ \\
\hline SAMPLE F & $12.9 \mathrm{ml}$ & $13.0 \mathrm{ml}$ & $13.1 \mathrm{ml}$ & $14 \mathrm{ml}$ & $14.5 \mathrm{ml}$ \\
\hline SAMPLE G & $7.0 \mathrm{ml}$ & $8.0 \mathrm{ml}$ & $9.0 \mathrm{ml}$ & $9.9 \mathrm{ml}$ & $10.0 \mathrm{ml}$ \\
\hline SAMPLE H & $6.5 \mathrm{ml}$ & $8.9 \mathrm{ml}$ & $9.9 \mathrm{ml}$ & $10 \mathrm{ml}$ & $10.1 \mathrm{ml}$ \\
\hline
\end{tabular}

Table 3: Hourly Water Recovery of IMOR3-023L Emulsion(Toluene and SLS kept constant)

\begin{tabular}{|l|l|l|l|l|l|}
\hline Time & $\mathbf{1} \mathbf{h r}$ & $\mathbf{2} \mathbf{~ h r s}$ & $\mathbf{3} \mathbf{h r s}$ & $\mathbf{4 h r s}$ & $\mathbf{5} \mathbf{h r s}$ \\
\hline SAMPLE I & $3.0 \mathrm{ml}$ & $5.0 \mathrm{ml}$ & $8.0 \mathrm{ml}$ & $9.0 \mathrm{ml}$ & $9.9 \mathrm{ml}$ \\
\hline SAMPLE J & $12 . \mathrm{ml}$ & $12.5 \mathrm{ml}$ & $12.6 \mathrm{ml}$ & $12.8 \mathrm{ml}$ & $12.9 \mathrm{ml}$ \\
\hline SAMPLE K & $4.0 \mathrm{ml}$ & $6.0 \mathrm{ml}$ & $7.0 \mathrm{ml}$ & $9.0 \mathrm{ml}$ & $10.0 \mathrm{ml}$ \\
\hline SAMPLE L & $3.9 \mathrm{ml}$ & $4.9 \mathrm{ml}$ & $5.0 \mathrm{ml}$ & $7.1 \mathrm{ml}$ & $8.9 \mathrm{ml}$ \\
\hline
\end{tabular}

Table 4: Hourly Water Recovery of AGBDI - 013L Emulsion (SLS and Toluene Volumes kept constant)

\begin{tabular}{|l|l|l|l|l|l|}
\hline Time & $\mathbf{1} \mathbf{~ h r}$ & $\mathbf{2} \mathbf{~ h r s}$ & $\mathbf{3} \mathbf{h r s}$ & $\mathbf{4 h r s}$ & $\mathbf{5}$ hrs \\
\hline SAMPLE W & $9.0 \mathrm{ml}$ & $11.2 \mathrm{ml}$ & $12.5 \mathrm{ml}$ & $13.0 \mathrm{ml}$ & $13.0 \mathrm{ml}$ \\
\hline SAMPLE X & $11.0 \mathrm{ml}$ & $11.9 \mathrm{ml}$ & $12.1 \mathrm{ml}$ & $12.2 \mathrm{ml}$ & $12.5 \mathrm{ml}$ \\
\hline SAMPLE Y & $11.0 \mathrm{ml}$ & $13.2 \mathrm{ml}$ & $14.0 \mathrm{ml}$ & $14.1 \mathrm{ml}$ & $15.0 \mathrm{ml}$ \\
\hline SAMPLE Z & $10.8 \mathrm{ml}$ & $13.0 \mathrm{ml}$ & $13.2 \mathrm{ml}$ & $14.0 \mathrm{ml}$ & $14.5 \mathrm{ml}$ \\
\hline
\end{tabular}

It can be observed that for samples A and D (Table 1), a significant amount of water was separated after 10minutes $(9 \mathrm{ml}$ and $10 \mathrm{ml}$ respectively). After 1 hour more water was separated $(13 \mathrm{ml}$ and $14 \mathrm{ml}$ respectively).It is also noted that sample $\mathrm{A}$ and $\mathrm{D}$ achieved a higher volume of separation than sample C and D where the quantity of SLS was $1 \mathrm{ml}$ and $4 \mathrm{ml}$ respectively. The maximum volume of separation occurred at sample D in which the initial volume of water added to form the emulsion was $12 \mathrm{ml}$ and the volume of water separated from the sample was $15 \mathrm{ml}$.This was achievable when the volume of SLS used was $4 \mathrm{ml}$ (at its highest).The extra volume of water separated was due to the fact that the crude contains water. The exact volume of water added to form the emulsion sample $F$ was the volume of water separated at the end of the 5 hours interval, while for the other samples $(\mathrm{E}, \mathrm{G}, \mathrm{H})$ in Table 2, significant increase occurred in the volume of water separated at the end of the 5hrs interval but they were not able to recover the volume of water added to form the emulsion. Since for both crude samples the volume of hexane and toluene were kept constant at varying condition of SLS, it therefore indicates that the effect of surfactant on the treatment of crude oil emulsion is a function of emulsion type and the properties of the crude.

The results in Tables (3-4) were generated under a test case of constant SLB and Toluene. The results show that increase in the demulsifier (Hexane) increased the volume of water separated, this is seen in sample $\mathrm{J}$ where maximum volume of water was separated as compared to Samples(I,K,L) where significant increase in volume of water separated was noted. Hence the higher volume of demulsifier (Hexane) used when surfactant(SLS) and stabilizer (Toluene) are kept constant the more effective the maximum volume of water separated. The result shows that maximum volume of water separated was evident in sample $\mathrm{Y}$ while sample $\mathrm{W}, \mathrm{X}$ and $\mathrm{Z}$ showed significant increase as the volume of demulsifier (Hexane) was increased at constant Toluene and SLS.

Figures 1 to 4 shows in detail the volume recovered with respect to time.

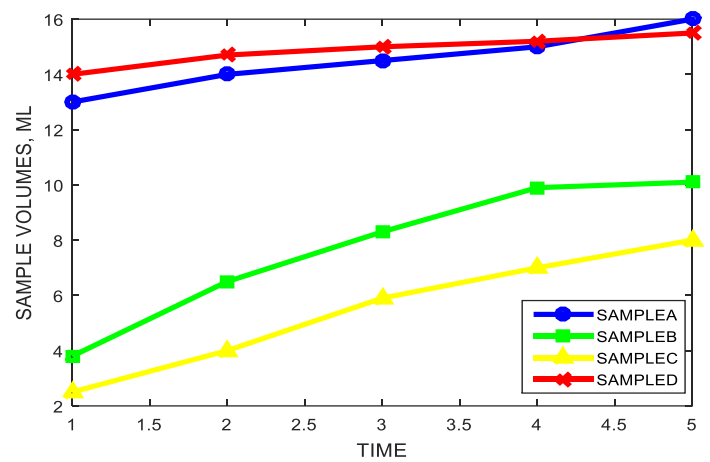

Figure 1: Water Volume Recovered from each Sample for AGBBI - 013L Emulsion (Hexane and Toluene Volumes kept constant)

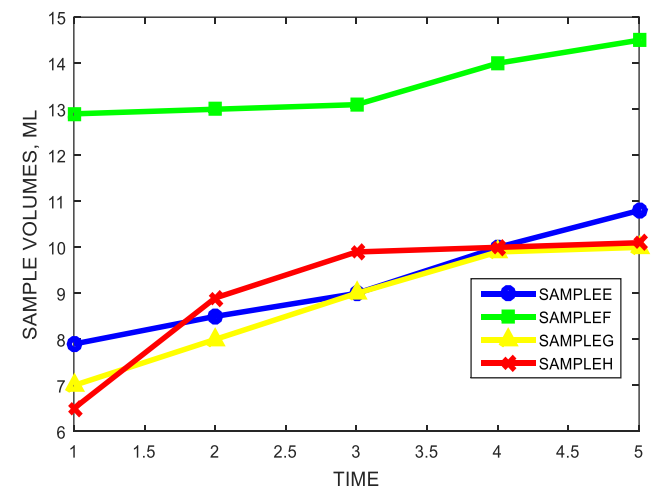

Figure 2: Water Volume Recovered from each Sample for (IMOR3-023L) Emulsion (Hexane and Toluene Volumes kept constant) 


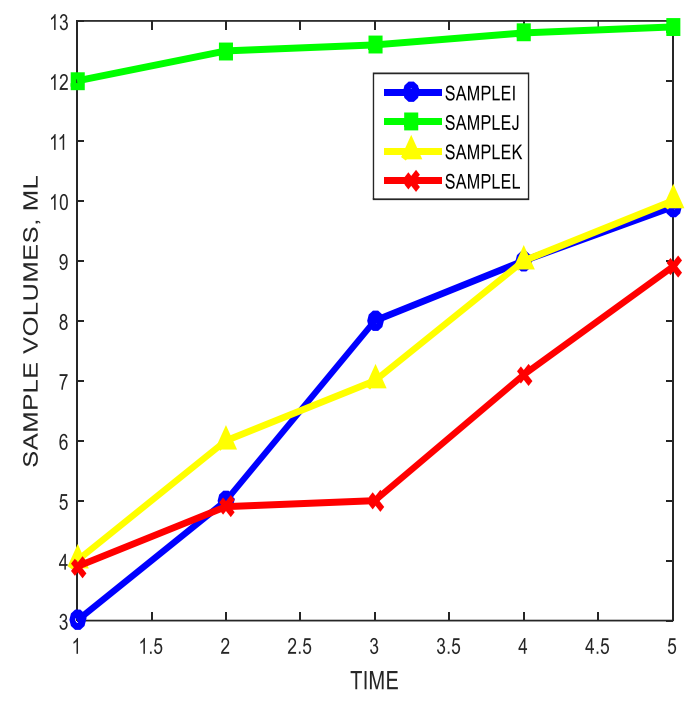

Figure 3: Water Volume Recovered from each Sample for (IMOR3-023L) Emulsion (SLS and Toluene Volumes kept constant)

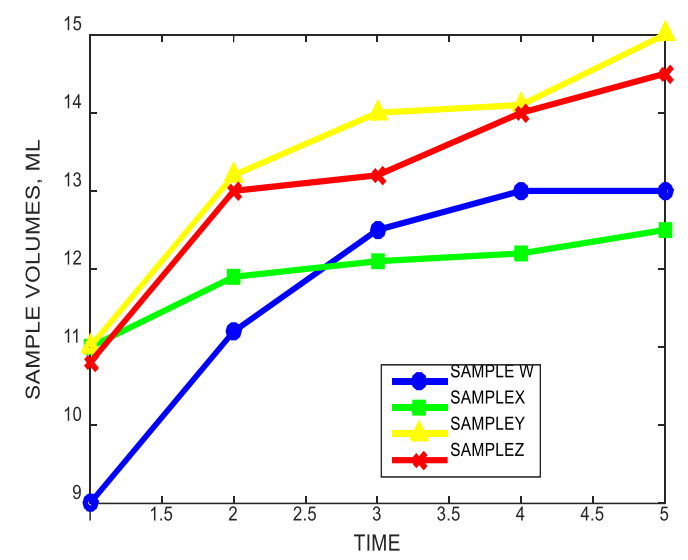

Figure 4: Water Volume Recovered from each Sample for (AGDBI - 013L) Emulsion (SLS and Toluene Volumes kept constant)

The result has proven that addition of surfactants and demulsifiers to a crude oil emulsion fosters the treatment of the emulsion by causing a phase separation of the crude and water phases. The major purpose of the surfactant is to modify the interfacial tension between the oil and water phases while the demulsifiers is an additive that mitigates and alleviates the formation of emulsions. The emulsion stability was monitored by measuring the volume of separated water from the emulsion by the test bottle method. Indeed, the lower the emulsion stability, the larger the water partition. The amount of separated water is directly correlated to the instability of the emulsion since destruction of the interfacial film and subsequent water droplet coalescence is the determinant step in the demulsification process. From the analysis of amounts of separated water for different volume concentrations of hexane (demulsifier) and surfactants, it is noticed that the maximum stability is observed for the emulsion containing the anionic surfactant, whereas the ionic surfactants confer lesser stability to the emulsion.

\section{- Effect of Surfactant on Crude Oil Physical Properties}

Since crude oil physical properties is very integral to emulsion formation and its treatment, a comparative analysis is presented in Tables (5-9). The crude oil density, viscosity, cloud point, pour point and $\mathrm{pH}$ values are tested under two test scenarios- crude oil with no surfactant and crude oil + surfactant. From the result of the physical properties before addition and after addition of surfactant it shows that there is decrease in density after the addition of surfactant for AGBD1-013L from 0.93g-0.85g and IMOR3-023LS from $0.95 \mathrm{~g}-0.90 \mathrm{~g}$. The viscosity of the crude also decreased significantly at the addition of surfactant, for AGBD1-013L from $(8.71-5.81) \mathrm{cm} / \mathrm{s}^{2}$ while for IMOR3-013L it decreased from $(31.61-24.30) \mathrm{cm} / \mathrm{s}^{2}$. The cloudpoint of the crude increased for $\mathrm{AGBD} 1-013 \mathrm{~L}$ from $\left(-2^{\circ} \mathrm{C}\right.$ to $\left.10.2^{\circ} \mathrm{C}\right)$ and for IMOR3-023L from $(-1 \text { to } 10)^{\circ} \mathrm{C}$. The pourpoint increased for AGBD1-013L from (-5 to -2$)^{\circ} \mathrm{C}$ and for IMOR3-023L from (9 to -1.3$)^{\circ} \mathrm{C}$. Also a significant increase in $\mathrm{PH}$ value for the two crude samples was noted on addition of surfactant. Hence the addition of surfactant in a crude oil caused a significant change in the physical properties of the crude. Details of the calculation are presented in Appendix B.

Table 5: Density of Sample

\begin{tabular}{|l|l|l|l|l|}
\hline Sample & $\begin{array}{c}\text { Wt of } \\
\text { Empty } \\
\text { pycn- } \\
\text { meter } \\
(\mathbf{g})\end{array}$ & $\begin{array}{c}\text { Wt of } \\
\text { Pycnometer } \\
\text { + crude oil } \\
\text { sample (g) }\end{array}$ & $\begin{array}{c}\text { B-A (Wt } \\
\text { of Crude } \\
\text { Oil } \\
\text { Sample) } \\
(\mathbf{g})\end{array}$ & $\begin{array}{c}\text { Densi } \\
\text { ty } \\
(\mathbf{g} / \mathbf{m l})\end{array}$ \\
\hline $\begin{array}{l}\text { AGBBI - } \\
\text { 013L }\end{array}$ & 14.68 & 37.93 & 23.25 & 0.93 \\
\hline $\begin{array}{l}\text { IMOR3 - } \\
\text { 023L }\end{array}$ & 14.68 & 38.55 & 23.87 & 0.95 \\
\hline $\begin{array}{l}\text { AGBB1- } \\
\text { 013L+ SLB }\end{array}$ & 14.68 & 35.95 & 21.27 & 0.85 \\
\hline $\begin{array}{l}\text { IMOR3- } \\
\text { 023L+ SLB }\end{array}$ & 14.68 & 37.20 & 22.52 & 0.90 \\
\hline
\end{tabular}

Table 6: Oil Viscosity Measured at a Temperature of $28^{\circ} \mathrm{C}$

\begin{tabular}{|c|c|c|}
\hline & \multicolumn{2}{|c|}{ Time of Flow (secs) } \\
\hline SAMPLES & $\begin{array}{c}\text { SAMPLE (No } \\
\text { Surfactant) }\end{array}$ & $\begin{array}{c}\text { SAMPLE + } \\
\text { Surfactant }\end{array}$ \\
\hline AGBDI 013L & 0.48 & 40 \\
\hline IMOR3 023L & 2.10 & 1.41 \\
\hline
\end{tabular}


Table 7: Cloud Point of Sample

\begin{tabular}{|c|c|c|}
\hline SAMPLE & \multicolumn{2}{|c|}{ CLOUD POINT $\left(^{\mathbf{0}} \mathbf{C}\right)$} \\
\hline & $\begin{array}{c}\text { SAMPLE (No } \\
\text { Surfactant) }\end{array}$ & $\begin{array}{c}\text { SAMPLE + } \\
\text { Surfactant }\end{array}$ \\
\hline AGBDI-013L & -2 & 10.2 \\
\hline IMOR3-023L & -1 & 10 \\
\hline
\end{tabular}

Table 8: Pour Point of Sample

\begin{tabular}{|c|c|c|}
\hline SAMPLE & \multicolumn{2}{|c|}{ POUR POINT $\left(^{\mathbf{0}} \mathbf{C}\right)$} \\
\hline & $\begin{array}{c}\text { SAMPLE (No } \\
\text { Surfactant) }\end{array}$ & $\begin{array}{c}\text { SAMPLE + } \\
\text { Surfactant }\end{array}$ \\
\hline AGBDI-013L & -5 & -2 \\
\hline IMOR3-023L & -9 & -1.3 \\
\hline
\end{tabular}

Table 9: pH Values @ Average Temperature of $26.0^{\circ} \mathrm{C}$

\begin{tabular}{|c|c|c|}
\hline SAMPLE & \multicolumn{2}{|c|}{ CLOUD POINT $\left({ }^{\mathbf{0}} \mathbf{C}\right)$} \\
\hline & $\begin{array}{c}\text { SAMPLE (No } \\
\text { Surfactant) }\end{array}$ & $\begin{array}{c}\text { SAMPLE + } \\
\text { Surfactant }\end{array}$ \\
\hline AGBDI-013L & 6.53 & 7.41 \\
\hline IMOR3-023L & 5.39 & 7.53 \\
\hline
\end{tabular}

\section{CONCLUSION}

In this study, the effects of SLS and hexane on crude oil emulsion treatment have been investigated using two different crude oil samples - AGBDI-013L and IMOR3-023L. The samples subjected to similar laboratory conditions and the results are comparatively and collectively analyzed. The result shows that surfactants and demulsifiers greatly affect the physical properties of crude oil by lowering the interfacial tension. Surfactants also lower crude oil density and viscosity and increases the cloud point, pour point and the $\mathrm{pH}$ Value. By formulating different emulsion samples, the results reveals that the extent of the effect of surfactants and demulsifiers will be dependent on the type of emulsion to be treated.

In this study, hexane and SLS were added simultaneously and the emulsion stability was measured. For future studies, these substances could be added separately while the stability is measured for each volume concentration.

\section{APPENDIX A \\ EMULSION PREPARATION}

The emulsion composed of the crude oil sample, the water, Toluene (stabilizer), SLS (surfactant), and hexane (demusifier). The total volume of each emulsion sample was equal to $50 \mathrm{ml}$.
Table 10: AGBDI - 013L Emulsion (Hexane and Toluene Volumes kept constant)

\begin{tabular}{|c|c|c|c|}
\hline \multicolumn{4}{|c|}{ Crude Oil Samples } \\
\hline \multicolumn{4}{|c|}{ AGBDI - 013L } \\
\hline \multicolumn{3}{|c|}{ SAMPLE A } & \multicolumn{2}{c|}{ SAMPLE B } \\
\hline Oil & $20 \mathrm{ml}$ & Oil & $20 \mathrm{ml}$ \\
\hline Water & $15 \mathrm{ml}$ & Water & $14 \mathrm{ml}$ \\
\hline Toluene & $4 \mathrm{ml}$ & Toluene & $4 \mathrm{ml}$ \\
\hline SLS & $1 \mathrm{ml}$ & SLS & $2 \mathrm{ml}$ \\
\hline Hexane & $10 \mathrm{ml}$ & Hexane & $10 \mathrm{ml}$ \\
\hline \multicolumn{2}{|c|}{ SAMPLE C } & SAMPLE D \\
\hline Oil & $20 \mathrm{ml}$ & Oil & $20 \mathrm{ml}$ \\
\hline Water & $13 \mathrm{ml}$ & Water & $12 \mathrm{ml}$ \\
\hline Toluene & $4 \mathrm{ml}$ & Toluene & $4 \mathrm{ml}$ \\
\hline SLS & $3 \mathrm{ml}$ & SLS & $4 \mathrm{ml}$ \\
\hline Hexane & $10 \mathrm{ml}$ & Hexane & $10 \mathrm{ml}$ \\
\hline
\end{tabular}

Table 11: IMOR3 - 023L Emulsion (SLS and Toluene Volumes kept constant)

\begin{tabular}{|c|c|c|c|}
\hline \multicolumn{4}{|c|}{ Crude Oil Samples } \\
\hline \multicolumn{4}{|c|}{ IMOR3 - 023L } \\
\hline \multicolumn{2}{|c|}{ SAMPLE E } & SAMPLE F \\
\hline Oil & $20 \mathrm{ml}$ & Oil & $20 \mathrm{ml}$ \\
\hline Water & $20 \mathrm{ml}$ & Water & $16 \mathrm{ml}$ \\
\hline Toluene & $4 \mathrm{ml}$ & Toluene & $4 \mathrm{ml}$ \\
\hline SLS & $1 \mathrm{ml}$ & SLS & $1 \mathrm{ml}$ \\
\hline Hexane & $5 \mathrm{ml}$ & Hexane & $9 \mathrm{ml}$ \\
\hline \multicolumn{2}{|c|}{ SAMPLE G } & \multicolumn{2}{|c|}{ SAMPLE H } \\
\hline Oil & $20 \mathrm{ml}$ & Oil & $20 \mathrm{ml}$ \\
\hline Water & $17 \mathrm{ml}$ & Water & $18 \mathrm{ml}$ \\
\hline Toluene & $4 \mathrm{ml}$ & Toluene & $4 \mathrm{ml}$ \\
\hline SLS & $1 \mathrm{ml}$ & SLS & $1 \mathrm{ml}$ \\
\hline Hexane & $8 \mathrm{ml}$ & Hexane & $7 \mathrm{ml}$ \\
\hline
\end{tabular}

Table 12: IMOR3 - 023LEmulsion (Hexane and Toluene Volumes kept constant)

\begin{tabular}{|l|l|l|l|}
\hline \multicolumn{4}{|c|}{ Crude Oil Samples } \\
\hline \multicolumn{3}{|c|}{ IMOR3 - 023L (Toluene and Hexane Constant) } \\
\hline SAMPLE I & SAMPLE J \\
\hline Oil & $20 \mathrm{ml}$ & Oil & $20 \mathrm{ml}$ \\
\hline Water & $15 \mathrm{ml}$ & Water & $16 \mathrm{ml}$ \\
\hline Toluene & $4 \mathrm{ml}$ & Toluene & $4 \mathrm{ml}$ \\
\hline SLS & $1 \mathrm{ml}$ & SLS & $3 \mathrm{ml}$ \\
\hline Hexane & $10 \mathrm{ml}$ & Hexane & $10 \mathrm{ml}$ \\
\hline SAMPLE K & & SAMPLE L \\
\hline Oil & $20 \mathrm{ml}$ & Oil & $20 \mathrm{ml}$ \\
\hline Water & $14 \mathrm{ml}$ & Water & $12 \mathrm{ml}$ \\
\hline Toluene & $4 \mathrm{ml}$ & Toluene & $4 \mathrm{ml}$ \\
\hline SLS & $2 \mathrm{ml}$ & SLS & $4 \mathrm{ml}$ \\
\hline Hexane & $10 \mathrm{ml}$ & Hexane & $10 \mathrm{ml}$ \\
\hline
\end{tabular}


Table 13: AGBBI - 013L (Toluene and SLS Constant)

\begin{tabular}{|l|l|l|l|}
\hline \multicolumn{4}{|c|}{ Crude Oil Samples } \\
\hline \multicolumn{4}{|c|}{ AGBDI - 013L } \\
\hline SAMPLE W & SAMPLE Y \\
\hline Oil & $20 \mathrm{ml}$ & Oil & $20 \mathrm{ml}$ \\
\hline Water & $20 \mathrm{ml}$ & Water & $17 \mathrm{ml}$ \\
\hline Toluene & $4 \mathrm{ml}$ & Toluene & $4 \mathrm{ml}$ \\
\hline SLS & $1 \mathrm{ml}$ & SLS & $1 \mathrm{ml}$ \\
\hline Hexane & $5 \mathrm{ml}$ & Hexane & $8 \mathrm{ml}$ \\
\hline SAMPLE X & & SAMPLE Z \\
\hline Oil & $20 \mathrm{ml}$ & Oil & $20 \mathrm{ml}$ \\
\hline Water & $15 \mathrm{ml}$ & Water & $18 \mathrm{ml}$ \\
\hline Toluene & $4 \mathrm{ml}$ & Toluene & $4 \mathrm{ml}$ \\
\hline SLS & $1 \mathrm{ml}$ & SLS & $1 \mathrm{ml}$ \\
\hline Hexane & $10 \mathrm{ml}$ & Hexane & $7 \mathrm{ml}$ \\
\hline
\end{tabular}

\section{APPENDIX B}

EXPERIMENTAL CALCULATIONS

\section{a. Density}

Weight of empty pycnometer $=14.48+0.25=14.68 \mathrm{~g}$

AGBDI-013L

Weight of pycnometer + crude oil $=37.68+0.25=37.93 \mathrm{~g}$

Weight of crude oil $=\mathbf{2 3 . 2 5 g}$

IMOR3-023L

Weight of pycnometer + crude oil $=38.30+0.25=38.55 \mathrm{~g}$

Weight of crude oil $=23.87 \mathrm{~g}$

$$
\begin{gathered}
\text { Specific gravity, } \rho=\frac{\rho_{o}\left(\frac{g}{m l}\right)}{\rho_{w}\left(\frac{g}{m l}\right)} \\
\text { But, Density }=\frac{\text { mass }}{\text { volume }} \\
A P I=\frac{141.5}{S G}-131.5
\end{gathered}
$$

$$
\begin{gathered}
A G B B I-013 L: D e n s i t y=\frac{23.25}{25}=0.93 \mathrm{~g} / \mathrm{ml} \\
\text { IMOR3 - 023L: Density }=\frac{23.87}{25}=0.95 \mathrm{~g} / \mathrm{ml}
\end{gathered}
$$

Density of water $=1 \mathrm{~g} / \mathrm{ml}$

Specific gravity of AGBDI-013L

$$
\text { Specific gravity }=\frac{0.93\left(\frac{g}{m l}\right)}{1\left(\frac{g}{m l}\right)}=0.93
$$

Specific gravity of IMOR-023L

$$
\begin{aligned}
& \text { Specific gravity }=\frac{0.95\left(\frac{g}{m l}\right)}{1\left(\frac{g}{m l}\right)}=0.95 \\
& \text { API of AGBDI }-013 \mathrm{~L}=\frac{141.5}{0.93}-131.5=\mathbf{2 0 . 6 5}^{\mathbf{A}} \mathbf{A}
\end{aligned}
$$

$$
\text { API of IMOR }-023 \mathrm{~L}=\frac{141.5}{0.95}-131.5=\mathbf{1 7 . 4 5}^{\mathbf{A}} \mathrm{A}
$$

b. Oil Viscosity

$$
\text { Using the formula: }
$$

$$
\left(A t-\frac{B}{t}\right) \mathrm{cm} / \mathrm{s}^{2}
$$

$$
\mathrm{A}=0.264, \mathrm{~B}=190
$$

for $40 \mathrm{~s}<\mathrm{t}<85 \mathrm{~s}$ $\mathrm{A}=0.247, \mathrm{~B}=65$

AGBDI- O13 L (Viscosity) [t $=48 \mathrm{sec}]$

$$
\left(0.264 \times 48-\frac{190}{48}\right)=8.71 \mathrm{~cm} / \mathrm{s}^{2}
$$

IMOR3 - O13 L (Viscosity) [t = $130 \mathrm{sec}]$

$$
\left(0.247 \times 130-\frac{65}{130}\right)=\mathbf{3 1 . 6 1} \mathrm{cm} / \mathbf{s}^{2}
$$

\section{a. Density}

\section{Results on Addition of Surfactant}

Weight of empty pycnometer $=14.48+0.25=14.68 \mathrm{~g}$ AGBDI-013L

Weight of pycnometer + crude oil $=35.70+0.25=35.95 \mathrm{~g}$

Weight of crude oil $=\mathbf{2 1 . 2 7} \mathrm{g}$

\section{IMOR3-023L}

Weight of pycnometer + crude oil $=36.95+0.25=37.20 \mathrm{~g}$

Weight of crude oil $=\mathbf{2 2 . 5 2 \mathrm { g }}$

$$
\begin{gathered}
\text { Specific gravity, } \rho=\frac{\rho_{o}\left(\frac{g}{m l}\right)}{\rho_{w}\left(\frac{g}{m l}\right)} \\
\text { But, Density }=\frac{\text { mass }}{\text { volume }} \\
\text { API }=\frac{141.5}{S G}-131.5 \\
\text { Volume of picnometer }=25 \mathrm{ml} \\
\text { AGBDI - 013L : Density }=\frac{21.27}{25}=\mathbf{0 . 8 5} \mathbf{g} / \mathbf{m l} \\
\text { IMOR3 - 023L: Density }=\frac{22.52}{25}=\mathbf{0 . 9 0} \mathbf{g} / \mathbf{m l}
\end{gathered}
$$

Density of water $=1 \mathrm{~g} / \mathrm{ml}$

Specific gravity of AGBDI-013L

$$
\text { Specific gravity }=\frac{0.85\left(\frac{g}{m l}\right)}{1\left(\frac{g}{m l}\right)}=0.85
$$

Specific gravity of IMOR-023L

$$
\text { Specific gravity }=\frac{0.90\left(\frac{g}{m l}\right)}{1\left(\frac{g}{m l}\right)}=0.90
$$




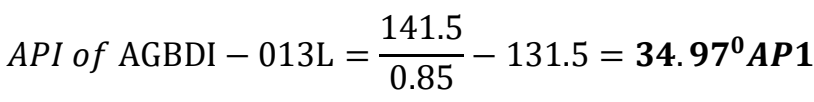

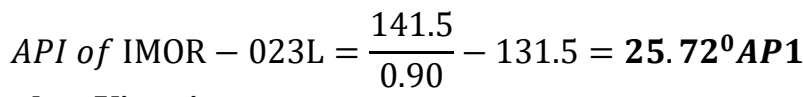

\section{b. Viscosity}

Using the formula:

$$
\left(A t-\frac{B}{t}\right) c m / s^{2}
$$

Where;

$$
\begin{array}{ll}
A=0.264, B=190 & \text { for } 40 \mathrm{~s}<t<85 \mathrm{~s} \\
A=0.247, B=65 & \text { for } 85 \mathrm{~s}<t<2000 \mathrm{~s}
\end{array}
$$

AGBDI- O13 L (Viscosity) [ $\mathrm{t}=40 \mathrm{sec}]$

$$
\left(0.264 \times 40-\frac{190}{40}\right)=\mathbf{5 . 8 1} \mathbf{c m} / \mathbf{s}^{2}
$$

IMOR3 - O13 L (Viscosity) $\mathrm{t}=101 \mathrm{sec}]$

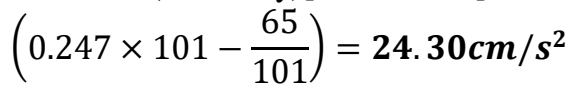

\section{REFERENCES}

1. Al-sabagh, AM., Nadia, .K.,Mahmoud,R., Noor,E. (2011). Functions of Demulsifihers in the Petroleum industry. Separation Science and Technology Journal. Pp11144-1146.

2. Golemanov, K., Denkov, N., Tcholakova, S., Vethamuthu, M., Lips. (2008). Surfactant Mixtures for Control of Bubble Surface Mobility in Foam Studies. Langmuir : the ACS journal of surfaces and colloids. $24.29956-61$. 10.1021/la8015386

3. Ijogbemeye, C. O., Akpabio, E. J., \& Udottong, G. (2012). Breaking of Oil -Water Emulsion for the Improvement of Oil Recovery Operations in the Niger Delta Oilfields. International Journal of Engineering and Technology, 2(11) 1854-1857.

4. Isreal, O. (2016). Experimental Study of the Rheology and Stability Behaviour of Surfactant Stabilized Water-in-oil Emulsion. Oklahoma: University of Oklahoma : Graduate College

5. Mazus, H. (2013). Experimental Investigation of Surfactant Effect On Abugia Crude Samples. Petraliu' De Caros 234-238.

6. Megahn, T. (2001). Demusification of Oil Emulsions. Texas, USA: Polly Publishing.
7. Oriji, A. B., \& Appah, D. (2012, January 1). Suitability of Local Demulsifier as an Emulsion Treating Agent in Oil and Gas Production. Society of Petroleum Engineers. doi:10.2118/162989-MS

8. Patricia, I. U. (2006). Predicting Water-In-Oil Emulsion Coalescence From Surface Pressure Isotherms. Calgary, Alberta: University of Calgary, Department of Chemical and Petroleum Engineering.

9. Pichot, R. (2012). Stability and Characterization of Emulsion in the Presence of Colloidal Particles and Surfactant. Uiniversity of Birmingham. Birmingham.

10. Raymond, J. (2003). Treating Oil Field Emulsions. Vancova: Relitic Press

11. Schubert \& Armbruster (1992). Emulsion Stability, in Encyclopedia of Emulsion Technology

12. Siti-Nuurul-Huda, M. A. (2010) Sepration of Crude Oil Emulsion Via Microwave Heating Technology. ResearchGates:https://www.researchgate.net/publicat ion/265654138, pp.2-4. 